\title{
The Theory and Practice of Dialogue Teaching in University Political Course
}

\author{
Zhiwu Zhou \\ Academy of Marxism, Guangdong University of Foreign Studies, Guangzhou, China \\ Email: 542921835@qq.com
}

How to cite this paper: Zhou, Z.W. (2017) The Theory and Practice of Dialogue Teaching in University Political Course. Open Journal of Social Sciences, 5, 190-193. https://doi.org/10.4236/jss.2017.54017

Received: March 22, 2017

Accepted: April 25, 2017

Published: April 28, 2017

Copyright $\odot 2017$ by author and Scientific Research Publishing Inc. This work is licensed under the Creative Commons Attribution International License (CC BY 4.0).

http://creativecommons.org/licenses/by/4.0/

\begin{abstract}
University political course is the main position to systemically educate undergraduates on Marxist theory. It has very important practical significance. Whereas, concerning the current situation of university political course, the teaching effectiveness has a considerable gap with its duty, which needs our introspection. From the perspective of dialogue teaching, this article discusses the theory and practice of political teaching in university.
\end{abstract}

\section{Keywords}

University Political Course, Teaching Dilemma, Dialogue Teaching

\section{Introduction}

As the main position to systemically educate undergraduates on Marxist theory, university political course is aimed to help students treat the socialism with Chinese characteristics with Marxist viewpoint and method. How to teach this course is one of the issues that college political teachers face with. To enhance the attraction and infectivity, political course must be oriented towards students' favor and lifelong benefit. Besides, it requires constantly strengthening and improving politics teaching, especially deepening the reform of teaching methods, in order to infuse new content and dynamism.

\section{The Idea of Dialogue Teaching Pattern}

Klingberg. L from Germany deems that dialogue in teaching process is not only exchanging teaching information, but also has its existence value and significance in a deeper level, as essential identity of excellent teaching [1]. Dialogue is a kind of fusion of horizons, which proceeds from the fore-structure of its subjects. Based on the equal and open basis, it lays emphasis on personality, thinking collision and inspiration [2]. The development of dialogue leads to promo- 
tion of the spirit of both teachers and students.

As for the college political class in particular, dialogue is confronted with a more complicated world, bearing the task of building foundation of cultivating students. Based on the equality between teachers and students, dialogue teaching is a teaching pattern that inspires students' autonomy, participation and creativity by variety modes of teacher-textbook dialogue, teacher-teacher dialogue, teacher-student dialogue, student-student dialogue, and teacher's self-dialogue, in order to stimulate learning interest and enthusiasm [3].

In college politics teaching, to implement dialogue well, both the teachers and students need the awareness of equality, openness and factualism. The sense of equality is the standpoint and premise of dialogue teaching. It refers that teachers and students carry out dialogue teaching smoothly in an equal position, rather than superior-subordinate relation. The sense of openness is the crucial point and emphasis. It means that everyone has the right to express their views without repressing neither by teachers nor students. Simultaneously, teachers and students are expected to reveal their true selves and express their thinking and feeling in an appropriate way. Only in this way can they achieve mutual psychological communication. The sense of factualism is the supporting point and difficulty. It requires both teachers and students to convey their thought on a realistic point of view, focusing on the center of problem instead of loosening their tongue like fairy scattering flowers. This will help more with thinking collision and problem solving.

\section{The Significance of Dialogue Teaching Pattern}

Firstly, in terms of teaching objective, training students from simply impacting knowledge to dynamic, creative and discourse-rational modern Homo sapiens is one of the major purposes of college education, college political course in especial.

Secondly, in the aspect of teaching ethics, teacher-student relationship enhances when it changes from teacher-oriented authority relation to democratic, equal and harmonious relation. Furthermore, it will deepen students' favor of political class. Teacher-student relationship transforming from traditional obedience to equality is in accordance with the development view of modern education.

Thirdly, concerning teaching concept, emphasis on students' individuality and challenge to current text-oriented teaching situation rebuild a new teaching order. It embodies a new autonomous learning concept and enhances the initiative of students. What's more, it conforms to the development view of individualized education and deepens students' favor of political class in a further step.

\section{The Application Forms of Dialogue Teaching Pattern}

First of all, teacher-text dialogue, namely, the dialogue between teacher and textbook or teaching materials, is the precondition and starting point of dialogue teaching pattern. Textbook content, the gist of teaching content, is compiled ac- 
cording to educational objectives and the needs of teaching. Only when college politics teachers grasp and master the textbook content fully, can they design commendable teaching content, have good communication with other teachers, and clear up the confusion from students.

The second form is teacher-teacher dialogue, including the dialogue between teachers and specialists, and the dialogue between teachers and their colleague. College teachers are not very knowledgeable about political course because of the constraints of their major learning and professional knowledge. Therefore, they have to seize every opportunity to consult specialists both inside and outside school. In addition, they can attend various training sessions and conferences of political course. If necessary specialists can be invited to class, discover the deficiency and give valuable suggestions through evaluation. This is more important for teachers to improve their professional and theoretical level.

Teacher-colleague dialogue is instructional discourse that conducted by teachers and their workmates in the same department. For one thing, enlightened from dialogue with colleagues before class, teachers are able to gather better teaching materials and methods, and then provide the best teaching approach. For another thing, through dialogue after class, they are capable of finding out the disparity and deficiency. Meanwhile, by sharing others' successful experience, they complement one another and comprehend by analogy.

Next one is teacher-student dialogue, which checks up and improves the suitability of teaching contents and teaching points by feedback from communication and interaction between teachers and students. It is the important measure and key of dialogue teaching pattern. Moreover, it can increase comprehension and trust, and actually benefits teachers as well as students. Teacher-student dialogue consists of dialogue between teacher and class, and dialogue with student.

In teacher-class dialogue, teachers are supposed to build up conversation according to the knowledge level of student, concerning the design of teaching issues, the setting of teaching points and the adoption of teaching methods. Lots of students from comprehensive university are not necessarily from liberal arts, but also from sciences. Hence, in politics teaching, teachers should begin with inspiring students' interest and initiatively talk with students to know their knowledge level, professional quality and fondness. To stimulate every student's learning enthusiasm and autonomy, dialogue is required to center on problems, be led by case and use discussion as method.

Teacher-student dialogue often takes place in explanation and discussion of teaching difficult problems in classroom instruction process, the supplement of teaching points and comprehension of difficult problems after class. By question-answer, query, debate and other specific means, teachers encourage students speak out their own ideas and thoughts, and help them change from absorbing knowledge passively to participating in teaching activities autonomously. Certainly, teachers are demanded to give guidance, control the process and direction of dialogue. Information exchange and problem solving should be carried on under an emotional state of understanding each other and active acceptance. 
The fourth is dialogue among students. As one of the synthetic disciplines, knowledge and viewpoints in college politics are inextricably linked with modern society. Nevertheless, owing to social influence and professional reality, students are likely to consider political course to be dull and boring. To deal with this problem, students can discuss some issues with practical significance. Dialogue among students has a variety of forms. It could be conversation in group members, or between two students. With dialogue advancing, problems are presented more clearly, thus promoting the socialized development of individual student.

The last one is teacher's self-dialogue. It means that teachers dissect their own classroom instruction in different dimensions and all aspects, to find out, study and work out problems, rather than soliloquy or mere self-analysis. In general, self-dialogue of conceptual course teacher is after-class experience analysis.

Every time class is over, teachers had better keep an account of the merits and demerits by means of diary. They can also sum up their experience in teaching process once a week, particularly recording the good and difficult courses in details. Consequently, teachers obtain more, and provide a possibility of better carrying out politics teaching.

\section{Epilogue}

French educator Mialaret said that the democratization of education has already become an inherent goal of nearly all educational reforms and innovations. It is a basic trend of current global education system evolution. Teachers and students have exchanges and dialogues in an atmosphere of equality and mutual respect. The ideas and characteristics of dialogue fully embody in dialogue teaching, thereby achieving the desired teaching effects. The new situations and problems encountered by students are brought into the classroom in teacherstudent dialogue and student-student dialogue. Additionally, conducting extensive and in-depth dialogue about the new problems not only broadens students' horizon, but also improves the abilities of debating, thinking, analyzing and solving the practical problems.

The practice has proved that dialogue teaching has good reference for improving college politics teaching. Great emphasis is laid to the value orientation of textbook contents, and the attraction of politics itself. Dialogue teaching respects the unique experience of each student in the learning process, and advocates autonomous, cooperative and inquiry learning styles. To perfectly show the social value of college political course, we should believe that dialogue teaching will have a good effect in the future teaching practice.

\section{References}

[1] Bom, D. (2004) On Dialogue. Education Science Press, Beijing.

[2] Zhu, D.Q. and Wang, M. (2003) On the Mode and Strategy of Dialogue Teaching. Research on Higher Education.

[3] Liu, J. (2007) On the Classroom Dialogue Teaching in Colleges and Universities, Journal of Jilin College of Education. 
Submit or recommend next manuscript to SCIRP and we will provide best service for you:

Accepting pre-submission inquiries through Email, Facebook, LinkedIn, Twitter, etc. A wide selection of journals (inclusive of 9 subjects, more than 200 journals)

Providing 24-hour high-quality service

User-friendly online submission system

Fair and swift peer-review system

Efficient typesetting and proofreading procedure

Display of the result of downloads and visits, as well as the number of cited articles Maximum dissemination of your research work

Submit your manuscript at: http://papersubmission.scirp.org/

Or contact jss@scirp.org 